$\$$

\title{
Geotechnical and geochemical appraisal of IFON clay, Southwestern Nigeria: Implications for industrial utilization
}

\author{
Ademila O*, Ogunribido T. H. T, Abidoye J. M \\ Department of Earth Sciences, Adekunle Ajasin University, Akungba-Akoko, Nigeria. \\ *Corresponding author E-mail:omowumi.ademila@aaua.edu.ng
}

\begin{abstract}
Clays are geological materials of economic potential in the manufacturing and environmental industries. Geotechnical properties and geochemical composition of Ifon clay deposits in Ondo State, Nigeria were investigated with the aim of determining their economic potentials. The geotechnical investigation includes consistency limits, strength, permeability and firing tests, while, X-ray fluorescence (XRF) method was used for determination of the bulk elemental composition of the clays using standard techniques. Geotechnical appraisal of the clay deposits revealed that high proportion of clay size fractions $(52.3-66.1 \%)$ makes the clays suitable in their natural state for industrial raw materials. Activity of the clays was found to be low at approximately $0.3-0.7$ and classified as inactive clays. Unconfined compressive strength varies between $3.4 \mathrm{~N} / \mathrm{mm}^{2}$ and $4.7 \mathrm{~N} / \mathrm{mm}^{2}$ and moderate shrinkage values $(\leq 12 \%)$ indicate that the clays could be used as building construction materials. Coefficient of permeability of $7.75 \times 10^{-8}$ to $1.72 \times 10^{-5} \mathrm{~cm} / \mathrm{sec}$ described the clays as low to impermeable soils suitable as barrier soils. $\mathrm{SiO}_{2}(64.41-68.74 \%)$ and $\mathrm{Al}_{2} \mathrm{O}_{3}(22.98-28.45 \%)$ contents dominate the clay geochemistry followed by iron oxide, $\mathrm{Fe}_{2} \mathrm{O}_{3}(3.57-8.31 \%)$ content among other oxides in traces, imply that they originated from underlying basement rocks subjected to varying degree of weathering. $\mathrm{Low} \mathrm{MgO}, \mathrm{CaO}, \mathrm{K}_{2} \mathrm{O}$ and $\mathrm{Na}_{2} \mathrm{O}$ indicate no expandable clay minerals in the clays. The clays show low heavy metal concentrations which guarantee their suitability as raw materials in chemical industries. Thus, Ifon clay deposits are suitable for the production of ceramics, refractory bricks, paper, paints, rubber and fertilizer.
\end{abstract}

Keywords: Activity; Geochemistry; Geotechnical Properties; IFON clay deposits; Industrial Utilization.

\section{Introduction}

Clay is applied to materials having a particle size of less than 2 micrometers and to the family of minerals that has similar chemical compositions and common crystal structural characteristics (Velde, 1995). Clays are chemically hydrous aluminum silicates, ordinarily containing impurities like potassium, sodium, calcium, magnesium or iron in small amounts, and are characterized by sheet silicate structures of composite layers stacked along the c-axis (Grim, 1968). They are naturally occurring materials that composed primarily of finegrained minerals, plastic at appropriate water contents and susceptible to hardening when fired at high temperature (Dogan et al., 2002). They may be composed of mixtures of clay minerals and clay-sized crystals of other minerals such as quartz, carbonate and metal oxides. Plasticity, little shrinkage during drying and firing and good strength are the most important properties of clay. The variation in mineralogical and engineering properties of clays depend on the make-up of the parent rock, topography, cliamte, vegetation, length of weathering and other factors. Clays are valuable resources in many industries that either manufacture products directly from clay or utilize clay when processed. Clays and clay minerals are economic minerals that have been found useful in manufacturing and environmental industries where they serve as major raw materials in the manufacture of heavy clay products like building and paving bricks, sewer pipes and drain tiles. They are also used in the production of ceramic wares, fertilizers, floor and wall tiles, paper, refractory, paint, rubber products, drilling mud, plaster of paris and pharmaceutical products. Other applications of clays include cure of ulcers, for cleansing purposes, detoxification, adsorption, skin emulsifiers and cure against dysentery and cholera (Mpuchane et al., 2008). Clays as minerals and rocks or soils are widely distributed and may be found in all geologic environments. Prolonged and extensive weathering alters the primary rock forming minerals to clay minerals and under favourable conditions leads to the development of clay deposits of economic interest. The location of the country within the tropical region of the world with alternating dry and wet seasons and relatively high humidity led to the widespread of clay deposits in Nigeria. This is encouraged by intensive chemical weathering of pre-existing crystalline rocks and feldspar minerals or hydrothermal alteration of granitic rocks. Elemental or chemical analysis is an important step of establishing the nature of minerals such as clay (Newman, 1987). The nature of a clay and its composition determine its quality, commercial value and engineering behaviour of the clay. Investigation of the chemical composition, as well as a good knowledge of the geotechnical properties of clays would make possible a more precise prediction of behaviour and incessant structural failures encountered in engineering works, would be avoided. Clay can serve as durable building materials, thus encouraged to be utilized to reduce total reliance on cement in Nigeria. Structural walls like compressed earth blocks and masonry brick work are clay based buildings built by stacking building blocks or bricks by forming the clay mixture into individual units which are then dried or fired. The demand for mineral exploration, utilization of mineral resources and increase in building and infrastructural projects 
has necessitated this study. The more mineralogical and geotechnical data that are available on clay bodies, the better, as this can lead to more effective understanding of their engineering performance and industrial suitability (Ademila and Adebanjo, 2017). Relatively little geological and geotechnical information on the properties of several clay deposits have limited their industrial utilization despite their large occurrence in the country. Hence, this study aims in assessing the economic potential of the clay deposits by evaluating the geotechnical and geochemical properties of the residual clay with the hope that the information will add to our understanding of the industrial applicability of clay deposits. The success of this study will help in promoting the utilization of the clay deposits, creation of employment opportunities and ensure sustainable economic growth of the communities in which they occur and the nation through mineral resource exploitation.

\section{Location and geology of the study area}

The town of Ifon is the headquarters of Ose Local Government area of Ondo State, Nigeria. It lies between latitudes $6^{\circ} 54^{\prime} \mathrm{N}$ and $6^{\circ} 57^{\prime} \mathrm{N}$ and longitudes $5^{\circ} 44^{\prime} \mathrm{E}$ and $5^{\circ} 47^{\prime} \mathrm{E}$ as shown in Fig. 1. The town is situated in the humid tropical region of Nigeria, characterized by alternating wet and dry seasons with a mean annual rainfall of over $1,500 \mathrm{~mm}$. The area is also characterised with a fairly uniform temperature and high relative humidity. The town covers a total area of about 5 square kilometres and lies at about the mid-point on the Federal Highway that connects Akure (the state capital of Ondo State) and Benin City (the capital city of Edo State). It is bounded to the North by Ikaro, Ipele to the west, Sabongida-Ora to the east and to the south by Ijagba. Inhabitants of this town are mainly indigenes of the town and government workers. This restricts their occupation mainly to farming and civil service. The area is drained by the River Ohin and the River Ose, which are seasonal. The two rivers dominate the drainage system of the study area, and it is mainly dendritic. Groundwater in the study area flows in the north to south direction.

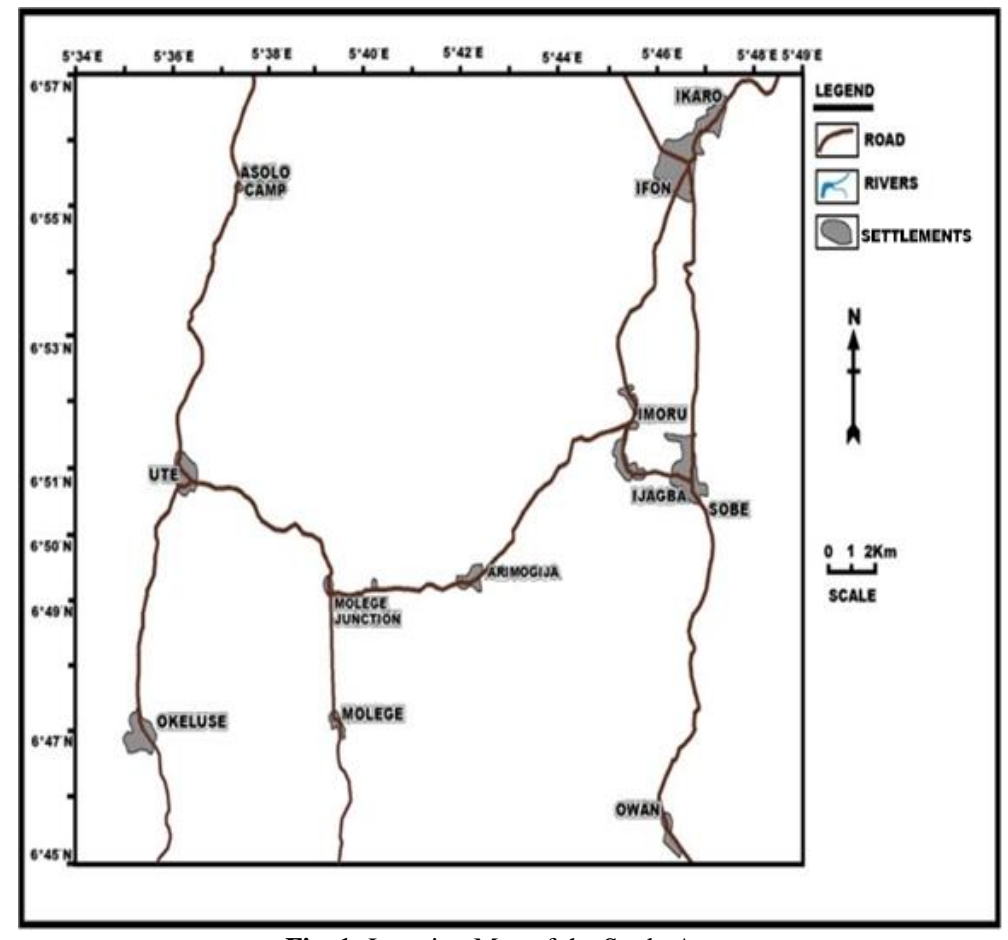

Fig. 1: Location Map of the Study Area.

Geologically, the study area falls within the sedimentary complex of southwestern Nigeria, which forms part of the eastern Dahomey basin consisting of sandstone, limestone, shale and clays. Ifon is located in the Eastern part of the Dahomey basin, underlain by the Cretaceous sediments of the Abeokuta Group (Fig. 2). This area is of geologic interest as it shows sedimentary succession that occurs as a road cut along the road from Owo to Ifon town. The study area, Ifon and environs are made of clastic sediment which forms part of the Dahomey basin in southwestern Nigeria. The area is underlain by ferrogenized sandstone, shale, mudstone, clay stone and sandy shale. The area is dominated by ferrogenous sandstone which is observed to occur alongside some shale mudstones and laterite. The succession from base to top is essentially of conglomerate-sandstone-siltstone-clay and lateritic cappings. The sandstone body is of varying thickness and the clay deposit lie above it. The clay deposit is mostly reddish brown in colour, very fine and indurated. The sandstone in this area are moderately sorted, leptokurtic with skewness ranging from being finely skewed to nearly symmetrical and it is continental in origin (high energy environment) (Agagu, 1985). The shales are light grey to black, lightly fissile, well laminated and mostly marine with high organic content indicating a low energy environment. 


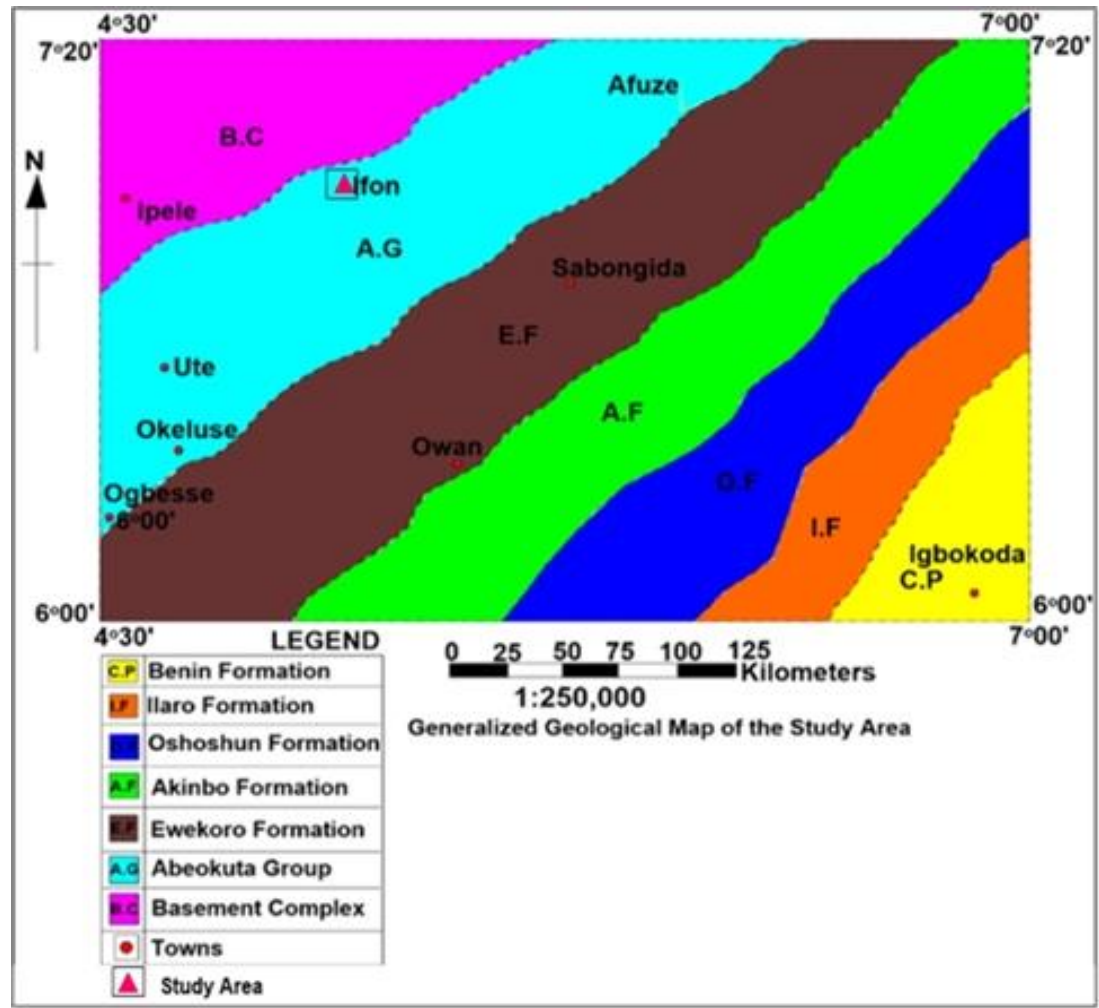

Fig. 2: Generalized Geological Map of Ifon and Its Environs.

\section{Materials and methods}

\subsection{Sampling and sample preparation}

Detailed geological fieldwork was conducted to obtain required data. The method involves sampling of clays, geotechnical and bulk elemental composition analysis of the clay samples. Fifteen (15) representative clay samples were collected from different clay deposits of the study area for geotechnical tests and analyzed for major, minor oxides and trace element using X-ray fluorescence spectrometer (XRF). The clays were collected at $1.5 \mathrm{~m}$ depth from freshly exposed surfaces of the clay bodies to get a good representation of the study area. The exposed surface of the clay was scraped to remove any dirt using a hand trowel. The sample collection was done in a systematic way so as to ensure proper collection of samples and total coverage of the study area. A global positioning system (GPS) was used at each sample station to measure coordinates of the station and heights above sea level. On the field, the clay exposures were observed and described based on their grain sizes, colour and texture. All the clay samples were carefully labeled in sample bags and then taken to the laboratory in sealed polythene bags to prevent contamination and loss of moisture. The samples were prepared for testing by crushing using a jaw crusher, followed by gently grinding the samples to avoid destruction of the structure of the mineral constituents. Samples were ground in a clean agate mortar to obtain powder form and then sieved to remove finer sand particles. Prepared samples were airdried for two weeks immediately after removing samples for the determination of moisture content to facilitate the sieving process in the laboratory for geotechnical investigation and chemical analysis.

\subsection{Geotechnical tests}

The following laboratory tests were conducted on the representative samples: natural moisture content, specific gravity, consistency limits, linear shrinkage, grain size distribution, compaction, California bearing ratio (CBR), firing colour test, permeability and unconfined compressive strength. These laboratory analyses were carried out following British Standard Methods of test for soils (BS 1377:1990) and ASTM Standard D1557 (2009). Additionally, colloidal activity of the clay samples was computed by Skempton's (1953) formula. Wet sieving and sedimentation under gravity using Stokes law of settling velocity was conducted for grain size analysis. The clay soils were characterized and classified based on the above tests.

\subsection{Geochemical investigation}

The sample pellets prepared by combining the binding material were analyzed for major and minor oxides using an ARL 9900 series intellipower XRF spectrometer. $5 \mathrm{~g}$ of the pulverized sample was weighed into an aluminum milling plate, 6 pellets of ethylene glycol was added to the pulverized sample to act as binding agent. The mixture was thoroughly milled using a Gyro milling machine to ensure homogeneity for 3 minutes. The homogenized samples were placed in an aluminum cup and hydraulically pressed into pellets under high pressure with an automatic pressing machine for 2 minutes. The samples were labeled and ready for the analysis. This was done to ensure sample integrity under the vacuum and a consistent surface to receive the $\mathrm{X}$ - rays. 


\section{Results and discussion}

\subsection{Geotechnical characteristics}

The clay varies from yellowish grey to brown in colour and fine to medium grained in texture.

\subsubsection{Natural moisture content (NMC)}

Moisture content is useful in estimating soil mass responses. The natural moisture content of the analyzed clay soils ranged from $13.0-$ $27.8 \%$ (Table 1). This high moisture is an indication of a high water adsorption capability of the soil material. Moisture variation is determined by the amount of rain, depth of collection of sample and texture of the soil. The high percentage of moisture contents in all the clay samples conforms to the generally accepted high porosity and low permeability properties of clay. This result demonstrates the suitability of the clay soils as barrier materials.

\subsubsection{Specific gravity (Gs)}

The specific gravity of all the samples tested are in the range between $2.41-2.73$ (Table 1) with an average value of 2.58 . The specific gravity of soil grains is an important property in the identification and evaluation of aggregate parameters for construction purposes (Gidigasu, 1976). The higher the specific gravity of the soil, the better it is for construction purposes. The specific gravity values indicate that not all the clay samples met the specific standard ( $\geq 2.6)$, hence could not be used as road and building construction materials. The results also indicate that the clay samples of Locations L1 and L9 have the highest specific gravity and most dense of the clays while L3 clay is light and of lower density.

\subsubsection{Consistency limits}

The amount of water in the soil controls deformation behaviour for that soil, this behaviour is called soil consistency. This is also used to describe the degree of firmness of clay soil mass. The liquid limit (LL) of the clay soils ranged from $40.0 \%$ to $60.2 \%$ (Table 1 ), which is an indication of high plasticity of the clay (Whitlow, 1995). The high liquid limit values indicate a high water retention capacity of the clayey soils. The clay can be classified as inorganic soil based on the liquid limit values less than $100 \%$. The medium to high plasticity of the clay soils guarantees their suitability as barrier material for landfill to prevent migration of leachate to groundwater bodies to protect public health. The plastic limit (PL) of the clay soils ranged from $15.3 \%$ to $28.6 \%$. This shows that the clays are suitable for the production of ceramics, because these values are within the recommended range of $10 \%$ to $60 \%$ stipulated by Grimshaw, 1971 for ceramic production. Liquid limit and plasticity index (PI) are used to classify fine grained soils. Plasticity index of the soils ranged from $12.9 \%$ to $39.1 \%$ (Table 1). The high plasticity index showed the clays potential for great volume change characteristics. The higher the plasticity index of soils, the greater the engineering problems associated when used as engineering materials. The plasticity index of the clays showed that the clays could easily be moulded and processed for bricks, pottery and ceramics. Highly plastic clays can be mixed with cohesionless granular fine sand to reduce the plasticity. The plasticity of the clays can also be reduced by Base Exchange process. Combination of additives like lime $(\mathrm{CaO})$ and salt $(\mathrm{NaCl})$ greatly reduces plasticity index and swelling potential of soil materials $(\mathrm{Au}$ and Chae, 1980). The linear shrinkage (LS) of the clays obtained at $1200^{\circ} \mathrm{C}$ ranged from $7.7 \%$ to $12 \%$, which are within the internationally accepted range of $7-10 \%$ recommended for linear shrinkage for refractory clays (Chester, 1973; Ademila and Adebanjo, 2017), except the clay samples of Locations L13 and L14 that possess high shrinkage values > 10\%. High shrinkage values may result in cracking and distortion of end products of bricks, ceramics and pottery. The plot of the plasticity index against the liquid limits (Fig. 3); based on Casagrande (1948) chart classified the clay as inorganic clay of medium to high compressibility and moderate toughness. The plot implies that the clays are moderate to high in plasticity and swelling potential (12.9\% to $39.10 \%)$. The degree of scattering on the plasticity chart reflects the degree of variability of the clay soils and percentage content of fines. Based on the plasticity chart shown in Fig. 3, the clays fall in the category of CI-CH.

Table 1: Results of Natural Moisture Content, Atterberg Limits and Specific Gravity Tests of Ifon clays

\begin{tabular}{llllllll}
\multicolumn{1}{c}{ Table 1: Results of Natural Moisture Content, Atterberg Limits and Specific Gravity Tests of Ifon clays } \\
\hline Sample Code & NMC $(\%)$ & LL $(\%)$ & PL $(\%)$ & LS $(\%)$ & PI $(\%)$ & Gs & Unified Soil Classification \\
\hline L1 & 19.9 & 60.2 & 21.1 & 8.5 & 39.10 & 2.73 & CH \\
L2 & 16.6 & 48.1 & 28.6 & 9.6 & 20.30 & 2.48 & CI \\
L3 & 17.6 & 47.9 & 27.3 & 10.1 & 20.60 & 2.41 & CI \\
L4 & 25.0 & 47.1 & 15.3 & 9.1 & 31.80 & 2.46 & CI \\
L5 & 23.6 & 45.7 & 16.2 & 10.1 & 29.50 & 2.66 & CI \\
L6 & 17.7 & 48.3 & 22.8 & 10.1 & 25.50 & 2.51 & CI \\
L7 & 20.4 & 40.0 & 27.1 & 10.1 & 12.90 & 2.59 & MI \\
L8 & 26.3 & 46.0 & 24.7 & 9.1 & 21.30 & 2.54 & CI \\
L9 & 13.0 & 44.9 & 23.8 & 10.1 & 21.10 & 2.73 & CI \\
L10 & 25.7 & 47.3 & 24.0 & 10.1 & 23.30 & 2.57 & CI \\
L11 & 27.8 & 45.4 & 25.6 & 9.6 & 19.80 & 2.60 & CI \\
L12 & 23.4 & 46.9 & 24.0 & 7.7 & 22.90 & 2.50 & CI \\
L13 & 21.3 & 45.8 & 23.1 & 11.5 & 22.70 & 2.65 & CI \\
L14 & 20.7 & 53.9 & 26.5 & 12.0 & 27.40 & 2.67 & CH \\
L15 & 21.0 & 53.0 & 26.9 & 10.1 & 26.10 & 2.63 & CH \\
\hline
\end{tabular}




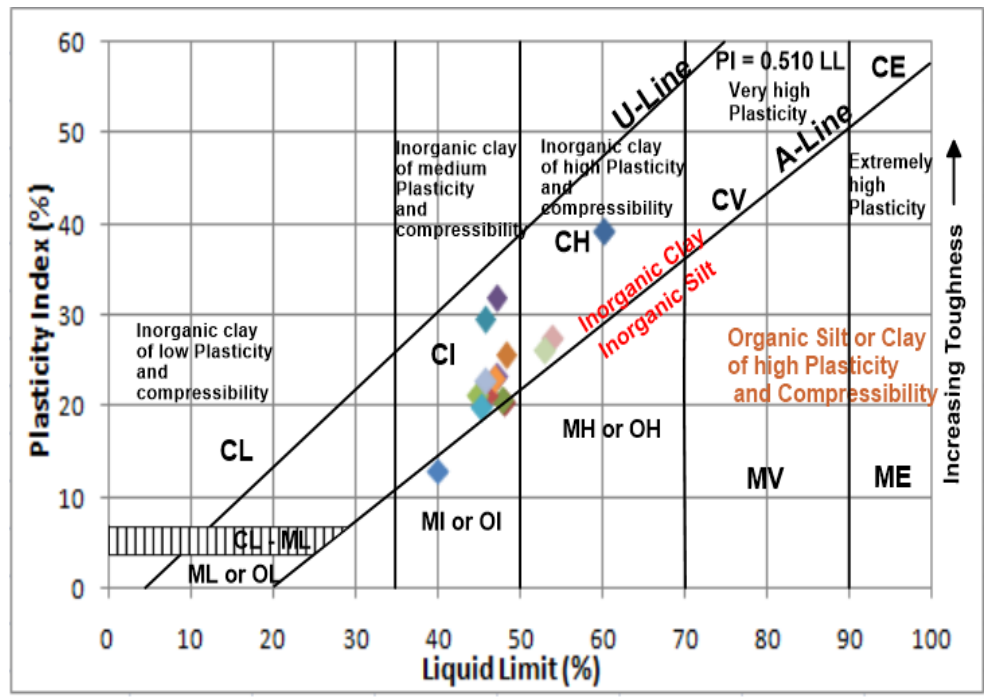

Fig. 3: Plasticity Chart for Classification of the Clay Deposits.

\subsubsection{Particle size analysis}

Results of the particle size analysis is presented in Table 2, it shows high percentage clay followed by sand then silt. This implies that the samples are less porous; thereby have an advantage in increasing their refractoriness. Rowe et al., 1995 recommended materials with high clay content or a high silt and clay content as the soils that will display low permeability for a sanitary landfill. Presence of pores in clay have impact on its strength causing reduction in the cross sectional area of the applied load. It can be observed that the soils have high proportion of fines $(>77 \%$ ) indicating that the soils have the tendency to shrink and swell repeatedly during alternate dry and wet seasons of the humid tropical climatic condition of the southwestern Nigeria, thereby causing distress on roads. Failures observed on roads are believed to be caused by pressures developed by the swelling soils. Also, the high clay content of the soils is an indication that they are not suitable as subgrade material. Thus, the clay soils suggest poor highway subgrade materials being clayey soil type (Ademila, 2018). Despite their high fines contents (77.9\% - 90.1\%), the high percentage of the clay-size fractions guarantees its usability in their raw nature as fillers and coating in paper, rubber, paint and cosmetic industries. Also, the appreciable amounts of sand-size particles $(9.5 \%-21.2 \%)$ make the soils suitable for large ceramic applications, making building blocks and bricks. The high fines content of the clay will ensure good compaction during moulding. Activity according to Skempton (1953) of the soil is the ratio of the plasticity index and the percentage of the clay fraction. It is a measure of the water holding capacity of the clayey soils. Soil activity value (Ac) is an indication of the type of clay minerals in the soil. The activity of the tested samples is in the range of 0.25 to 0.65 (Table 2 ); thus, the results portray the clay mineral contents in Ifon clay as inactive $(\mathrm{Ac}<0.75)$.

Table 2: Grain Size Distribution of Ifon Clays

\begin{tabular}{|c|c|c|c|c|c|c|c|}
\hline Sample Code & Clay (\%) & Silt (\%) & Sand (\%) & Gravel (\%) & Fines $(\%)$ & Activity & Remark \\
\hline L1 & 60.2 & 17.9 & 21.2 & 0.7 & 78.1 & 0.65 & Inactive \\
\hline L2 & 61.0 & 18.3 & 19.7 & 1.0 & 79.3 & 0.33 & Inactive \\
\hline L3 & 66.1 & 13.6 & 19.5 & 0.8 & 79.7 & 0.31 & Inactive \\
\hline L5 & 65.3 & 16.2 & 18.1 & 0.4 & 81.5 & 0.45 & Inactive \\
\hline L6 & 66.0 & 15.7 & 17.8 & 0.5 & 81.7 & 0.39 & Inactive \\
\hline L7 & 52.3 & 37.8 & 9.5 & 0.4 & 90.1 & 0.25 & Inactive \\
\hline L8 & 59.9 & 18.0 & 21.4 & 0.7 & 77.9 & 0.36 & Inactive \\
\hline L9 & 61.0 & 17.4 & 20.8 & 0.8 & 78.4 & 0.35 & Inactive \\
\hline L10 & 65.4 & 15.1 & 18.5 & 1.0 & 80.5 & 0.36 & Inactive \\
\hline L11 & 63.8 & 15.6 & 19.9 & 0.7 & 79.4 & 0.31 & Inactive \\
\hline L12 & 65.2 & 16.3 & 17.9 & 0.6 & 81.5 & 0.35 & Inactive \\
\hline L13 & 65.4 & 22.8 & 11.3 & 0.5 & 88.2 & 0.35 & Inactive \\
\hline L14 & 65.5 & 23.7 & 10.4 & 0.4 & 89.2 & 0.42 & Inactive \\
\hline $\mathrm{L} 15$ & 63.7 & 15.2 & 20.2 & 0.9 & 78.9 & 0.41 & Inactive \\
\hline
\end{tabular}

\subsubsection{Strength characteristics}

Compaction test results are shown in Table 3. The optimum moisture contents (OMC) are within the range $11.0 \%$ and $16.1 \%$ while, maximum dry density (MDD) varied between $1832 \mathrm{Kg} / \mathrm{m}^{3}$ and $2038 \mathrm{Kg} / \mathrm{m}^{3}$. From the results, it can be inferred that the clays are suitable for filling and embankment materials because the MDD is greater than $1680 \mathrm{~kg} / \mathrm{m}^{3}$ and OMC less than $18 \%$ (Federal Ministry of Works and Housing, 2000). It is also suitable for brick making materials in building construction with the MDD greater than $1650 \mathrm{~kg} / \mathrm{m}^{3}$ (Madedor, 1992). California bearing ratio is a semi-empirical test for evaluating highway subgrade/subbase soils. The unsoaked CBR value for the clay soils ranged from $14.0 \%-29.0 \%$ while the soaked CBR values ranged from $4 \%-10 \%$ (Table 3). None of the analyzed samples have the required $80 \%$ unsoaked and $30 \%$ soaked CBR value recommended for highway sub-base and sub-grade soils by the Federal Ministry of Works and Housing, 2000. The CBR values of the soils are generally low indicating low strength of the soil. From these results, the soils have shown their entire unsuitability subgrade materials in their natural state. Unconfined Compressive Strength (UCS) is an unconsolidated-undrained test used for clay specimens where the confining pressure $\left(\sigma_{3}\right)$ is zero $(0)$ and the major principal stress $\left(\sigma_{1}\right)$ is the unconfined compressive strength (qu). Its value is a measure of suitability of such soil as a foundation material. Table 3 shows the summary of unconfined compressive test results. The UCS ranged from $3.4 \mathrm{~N} / \mathrm{mm}^{2}$ to $4.7 \mathrm{~N} / \mathrm{mm}^{2}$. Although, these values are lower than the mean value $5.6 \mathrm{~N} / \mathrm{mm}^{2}$ reported by Mesida (1978) on some clay deposits in Nigeria but correlates with the average compressive 
strength of $3.0 \mathrm{~N} / \mathrm{mm}^{2}$ recommended by Aribisala, 1989 for clays for construction of bungalow and one storey building. This agrees with the suggestion that the clays could be used as building construction materials.

Table 3: Strength Properties of the Clay Soils of the Study Area

\begin{tabular}{|c|c|c|c|c|c|c|}
\hline \multirow[t]{2}{*}{ Sample Code } & \multicolumn{2}{|c|}{ Compaction characteristics } & \multicolumn{2}{|c|}{ California bearing ratio, CBR (\%) } & \multirow[t]{2}{*}{$\begin{array}{l}\text { Unconfined compressive } \\
\text { strength }\left(\mathrm{N} / \mathrm{mm}^{2}\right)\end{array}$} & \multirow[t]{2}{*}{ Permeability, $\mathrm{k}(\mathrm{cm} / \mathrm{sec})$} \\
\hline & $\operatorname{MDD}\left(\mathrm{Kg} / \mathrm{m}^{3}\right)$ & $\mathrm{OMC}(\%)$ & $\begin{array}{l}\text { Unsoaked CBR } \\
(\%)\end{array}$ & $\begin{array}{l}\text { Soaked CBR } \\
(\%)\end{array}$ & & \\
\hline L1 & 1941 & 13.4 & 23 & 6 & 3.6 & $7.43 \times 10^{-7}$ \\
\hline $\mathrm{L} 2$ & 1992 & 12.0 & 20 & 8 & 4.1 & $5.70 \times 10^{-7}$ \\
\hline L3 & 1909 & 15.0 & 18 & 6 & 3.9 & $3.02 \times 10^{-7}$ \\
\hline L4 & 1868 & 16.1 & 29 & 9 & 4.6 & $2.79 \times 10^{-7}$ \\
\hline L5 & 1949 & 13.2 & 20 & 9 & 4.4 & $4.75 \times 10^{-6}$ \\
\hline L7 & 1956 & 12.3 & 15 & 5 & 3.4 & $1.69 \times 10^{-6}$ \\
\hline L8 & 1857 & 14.8 & 23 & 10 & 3.7 & $1.72 \times 10^{-5}$ \\
\hline L9 & 1992 & 12.0 & 17 & 5 & 4.0 & $1.83 \times 10^{-6}$ \\
\hline L10 & 1980 & 12.3 & 16 & 6 & 4.2 & $1.10 \times 10^{-7}$ \\
\hline L11 & 2038 & 11.4 & 14 & 4 & 4.7 & $7.75 \times 10^{-8}$ \\
\hline L12 & 1923 & 14.6 & 27 & 10 & 4.3 & $9.24 \times 10^{-6}$ \\
\hline L13 & 2020 & 11.0 & 16 & 4 & 3.9 & $1.68 \times 10^{-7}$ \\
\hline L14 & 1932 & 13.3 & 16 & 9 & 3.5 & $8.51 \times 10^{-7}$ \\
\hline
\end{tabular}

\subsubsection{Permeability characteristics}

The permeability characteristic of a soil is an important parameter in its evaluation for use in engineering structures and as a barrier soil. The coefficients of permeability of the clay soils ranged from $7.75 \times 10^{-8} \mathrm{~cm} / \mathrm{sec}$ to $1.72 \times 10^{-5} \mathrm{~cm} / \mathrm{sec}$ (Table 3). Sample L8 has the highest value of permeability because it contains the highest amount of sand. Based on the classification by Lambe (1954), the permeability of $10^{-5} \mathrm{~cm} / \mathrm{sec}$ to less than $10^{-7} \mathrm{~cm} / \mathrm{sec}$ indicates a very low to practically impermeable soil. The coefficient of permeability values for all the clay samples tested were found to be in the range of $10^{-8}$ to $10^{-6}$ with the exception of clay L8 $\left(1.72 \times 10^{-5} \mathrm{~cm} / \mathrm{sec}\right)$ with the highest amount of sand. These values indicate that the clays analyzed are almost impermeable. The use of clay soils as barriers depends on its permeability characteristics. Soils with low permeability are the most desirable because in them the probability of groundwater pollution by vertical or lateral seepage is minimized. The clays therefore possess the permeability characteristics of good barrier soils in waste repository. Also, the high amount of fines and low content of gravel make the clays useful as soil liners.

\subsubsection{Firing characteristics}

The results of the firing tests are summarized in Table 4. The suitability of clay material for various industrial uses can be determined by percentage shrinkage and fired colour among other parameters. The firing temperature is an important factor enhancing the mechanical resistance and durability of finished products of ceramics, as the material becomes denser. It is also an important engineering quality index for building materials. The firing shrinkage at $1200^{\circ} \mathrm{C}$ revealed that linear shrinkage of the clay under consideration is between $7.7 \%$ and $12 \%$. The clay is suitable for ceramic, structural bricks and pottery works based on its shrinkage, since it shrinks no more than $12 \%$ (Robert, 1994). Presence of $\mathrm{SiO}_{2}$ (quartz) and $\mathrm{TiO}_{2}$ is responsible for low shrinkage observed in the clays. The fired colour is through grayish orange to light brown and reddish brown. These colours depend on the amount of the oxides of iron and titanium. Akpokodje et al., 1991 reported that clay with iron oxide above $2-3 \%$ will produce pinkish to reddish brown when fired. The iron oxide of the clays range from 4.25 to $8.31 \%$ and this is responsible for the fired colour in the tested samples. The reddish/brownish fired colours are preferred in the pottery and brick industries, whereas in some paper and paint industries, the creamy, whitish fired colours preferred can be acquired by bleaching the clay to produce buff colours needed for paper production.

\begin{tabular}{|c|c|c|c|}
\hline Sample Code & Color before firing & Color after firing & Fire ability \\
\hline L1 & Yellowish grey & Light brown & Fair \\
\hline L2 & Yellowish grey & Greyish orange & Good \\
\hline L3 & Yellowish grey & Reddish brown & Good \\
\hline L4 & Yellowish grey & Reddish brown & Good \\
\hline L5 & Brown & Light brown & Fair \\
\hline L6 & Yellowish grey & Light brown & Fair \\
\hline L7 & Medium grey & Light brown & Good \\
\hline L9 & Yellowish grey & Reddish brown & Fair to Good \\
\hline L10 & Yellowish grey & Reddish brown & Good \\
\hline L11 & Brown & Light brown & Good \\
\hline L12 & Brown & Light brown & Good \\
\hline L13 & Brown & Light brown & Good \\
\hline L14 & Yellowish grey & Light brown & Fair to Good \\
\hline L15 & Brown & Light brown & Fair to Good \\
\hline
\end{tabular}

\subsection{Geochemical characteristics}

The chemical compositions of the clays are presented in Table 5. The chemical analysis revealed the predominance of $\mathrm{SiO}_{2}(64.41-$ $68.74 \%$ ) and $\mathrm{Al}_{2} \mathrm{O}_{3}(22.98-28.45 \%$ ). These two oxides (average of $66.47 \%$ and $25.38 \%$ respectively) constitute the bulk chemical composition of the clays. The above concentration values suggest that the clay samples are hydrated siliceous aluminosilicates. Bain and Smith, 1987 proposed that quartz $\left(\mathrm{SiO}_{2}\right)$ may occur as fine disseminated crystalline particles in kaolinite or deposited with tiny flasks of the clay minerals. The mean values of $\mathrm{SiO}_{2}$ content of the clays above $66 \%$ implies that quartz is the major constituent of the clays, 
which will enhance the ceramic properties. High silica contents with moderate alumina and low concentrations of alkali, showed by the chemical characteristics denote kaolinitic features. Moderately high contents of alumina $\left(\mathrm{Al}_{2} \mathrm{O}_{3}\right)$ in the clays can be attributed to clay minerals and feldspar in the deposit. The higher the alumina content, the higher the quality of the refractory product. High composition of alumina can be extracted for the production of fertilizer and animal feeds and other products in which high alumina content is desired. The alumina content is within the standard for ceramics, paints, paper and refractory (Chester, 1973). The higher the alumina content, the higher the coefficient of thermal expansion of ceramic bodies. The clay is also suitable for the manufacture of high melting clays (1629\%) (Grimshaw, 1971; Chester, 1973). The ratio of $\mathrm{SiO}_{2} / \mathrm{Al}_{2} \mathrm{O}_{3}$ ranging from 2.27 to 2.94 indicates presence of siliceous sands which can be attributed to high quartz content of the clays. Relatively high amount of iron oxide, $\mathrm{Fe}_{2} \mathrm{O}_{3}(3.57-8.31 \%)$ in these samples can be attributed to the possible breakdown of biotite, augite and other ferromagnesium minerals of the source rocks. The composition of $\mathrm{Fe}_{2} \mathrm{O}_{3}$ less than $2 \%$ means that clay will fire white, while $\mathrm{Fe}_{2} \mathrm{O}_{3}$ greater than $2 \%$ suggests that clay will change colour to brownish or ruby-red depending on the percentages involved (Gupta, 2008). The relatively high concentration of the iron oxide is responsible for the grayish orange to light brown and reddish brown colour on firing. The high mean values of $\mathrm{Fe}_{2} \mathrm{O}_{3}(5.62 \%)$ is probably due to superficial oxidation. The $\mathrm{Fe}_{2} \mathrm{O}_{3}$ concentrations range from as low as $3.57 \%$ for $\mathrm{L} 15$ clay to as high as $8.31 \%$ for L10 clay signifying the higher degree of oxidation in $\mathrm{L} 10$ clay. Presence of $\mathrm{TiO}_{2}$ in the clays may reflect the association of titanium with discrete minerals in clay minerals especially kaolinite. The values of $\mathrm{TiO}_{2}(0.64-1.26 \%)$ in all the clay samples of the study area suggest the dissemination of the discrete minerals in the clays. High mean values of $\mathrm{Al}_{2} \mathrm{O}_{3}(25.38 \%)$ and $\mathrm{TiO}_{2}(1.00 \%)$ of the clays could be indicative of the effect of chemical weathering. As precipitation and chemical weathering increases, kaolinitization is enhanced. Low mean values of $\mathrm{CaO}, \mathrm{MgO}, \mathrm{Na}_{2} \mathrm{O}$, $\mathrm{MnO}$ and $\mathrm{K}_{2} \mathrm{O}(0.32 \%, 0.06 \%, 0.22 \%, 0.03 \%$ and $0.60 \%$ respectively) (Table 5) less than one percent each indicate little or no expandable clay minerals (montmorillonite) in the clays. In other words, the presence of alkalis and magnesia $(\mathrm{MgO})$ in the samples suggests presence of clay mineral which may not likely be montmorillonite. $\mathrm{MgO}, \mathrm{CaO}, \mathrm{Na}_{2} \mathrm{O}$ and $\mathrm{K}_{2} \mathrm{O}$ are fluxing agents which will reduce the vitrification of the clay in its use as refractory raw material, but will enhance the production of bricks and pottery wares due to early vitrification and energy conservation. Low $\mathrm{P}_{2} \mathrm{O}_{5}$ content could have been due to the lower amount of accessory phases, like monazite and apatite. Also, low $\mathrm{K}_{2} \mathrm{O}$ content indicates low amount of illite or $\mathrm{K}$-feldspar in the clays. Based on the silica/alumina ratio, proportions of $\mathrm{CaO}, \mathrm{Na}_{2} \mathrm{O}$ and $\mathrm{K}_{2} \mathrm{O}$, Ifon clay can be described as Fire clay. There is no much variation in the trace elements of the samples analyzed. Distribution of trace elements in the clays are influenced by weathering process and nature of the parent rocks (Nesbitt et al., 1980; Wronkiewicz and Condie, 1987). The heavy metals are present in negligible proportion that their presence would not pose threats to the performances of the clays as industrial raw materials. Thus, low concentrations of trace elements of the clays (Table 6) qualify their suitability as raw materials in chemical industries for the manufacture of powder, metallurgical products and as a catalyst.

\begin{tabular}{|c|c|c|c|c|c|c|c|c|c|c|c|c|}
\hline $\begin{array}{l}\text { Sample } \\
\text { Code }\end{array}$ & $\begin{array}{l}\mathrm{SiO}_{2} \\
(\%)\end{array}$ & $\begin{array}{l}\mathrm{Al}_{2} \mathrm{O}_{3} \\
(\%)\end{array}$ & $\begin{array}{l}\mathrm{Fe}_{2} \mathrm{O}_{3} \\
(\%)\end{array}$ & $\begin{array}{l}\mathrm{TiO}_{2} \\
(\%)\end{array}$ & $\begin{array}{l}\mathrm{MnO} \\
(\%)\end{array}$ & $\begin{array}{l}\mathrm{MgO} \\
(\%)\end{array}$ & $\begin{array}{l}\mathrm{CaO} \\
(\%)\end{array}$ & $\begin{array}{l}\mathrm{K}_{2} \mathrm{O} \\
(\%)\end{array}$ & $\begin{array}{l}\mathrm{Na}_{2} \mathrm{O} \\
(\%)\end{array}$ & $\begin{array}{l}\mathrm{P}_{2} \mathrm{O}_{5} \\
(\%)\end{array}$ & $\begin{array}{l}\text { SO3 } \\
(\%)\end{array}$ & $\begin{array}{l}\mathrm{SiO}_{2} / \mathrm{Al}_{2} \mathrm{O}_{3} \\
(\%)\end{array}$ \\
\hline L1 & 66.92 & 25.36 & 5.93 & 0.81 & 0.02 & 0.02 & 0.12 & 1.18 & 0.29 & 0.53 & 0.02 & 2.64 \\
\hline L2 & 68.74 & 23.37 & 5.62 & 0.64 & 0.02 & 0.01 & 0.55 & 0.84 & 0.16 & 0.5 & 0.01 & 2.94 \\
\hline L3 & 64.41 & 24.55 & 7.26 & 1.26 & 0.03 & 0.03 & 0.77 & 1.32 & 0.24 & 0.57 & 0.01 & 2.62 \\
\hline L4 & 67.18 & 23.83 & 5.79 & 0.88 & 0.02 & 0.04 & 0.34 & 0.63 & 0.42 & 0.5 & 0.02 & 2.82 \\
\hline L5 & 68.23 & 24.29 & 4.52 & 1.02 & 0.04 & 0.02 & 0.11 & 1.24 & 0.11 & 0.47 & 0.04 & 2.81 \\
\hline L6 & 65.19 & 25.93 & 5.18 & 0.93 & 0.02 & 0.06 & 0.08 & 0.39 & 0.23 & 0.48 & 0.01 & 2.51 \\
\hline L8 & 66.49 & 25.32 & 6.16 & 1.23 & 0.06 & 0.04 & 0.22 & 0.27 & 0.34 & 0.42 & 0.01 & 2.63 \\
\hline L9 & 68.15 & 24.13 & 5.26 & 1.15 & 0.02 & 0.16 & 0.16 & 0.13 & 0.52 & 0.54 & 0.02 & 2.82 \\
\hline L10 & 67.34 & 22.98 & 8.31 & 0.85 & 0.02 & 0.01 & 0.29 & 0.42 & 0.13 & 0.49 & 0.01 & 2.93 \\
\hline L11 & 66.52 & 25.61 & 5.16 & 1.52 & 0.02 & 0.03 & 0.51 & 0.52 & 0.26 & 0.5 & 0.01 & 2.60 \\
\hline L12 & 64.53 & 28.45 & 4.25 & 0.94 & 0.06 & 0.06 & 0.34 & 0.26 & 0.18 & 0.43 & 0.02 & 2.27 \\
\hline L13 & 67.32 & 24.51 & 6.06 & 0.78 & 0.03 & 0.26 & 0.16 & 0.63 & 0.05 & 0.54 & 0.02 & 2.75 \\
\hline L14 & 65.29 & 27.65 & 5.23 & 1.07 & 0.06 & 0.02 & 0.54 & 0.27 & 0.12 & 0.41 & 0.04 & 2.36 \\
\hline L15 & 64.67 & 28.13 & 3.57 & 1.12 & 0.04 & 0.04 & 0.43 & 0.35 & 0.22 & 0.56 & 0.01 & 2.30 \\
\hline
\end{tabular}

\begin{tabular}{|c|c|c|c|c|c|c|c|c|c|}
\hline Sample Code & $\mathrm{Cd}$ & $\mathrm{Co}$ & $\mathrm{Cr}$ & $\mathrm{Zn}$ & $\mathrm{Cu}$ & $\mathrm{Pb}$ & $\mathrm{Ni}$ & $\mathrm{V}$ & $\mathrm{Mn}$ \\
\hline L1 & 0.0009 & 0.0508 & 0.0093 & 0.1084 & 0.0612 & 0.0094 & 0.0680 & 0.0001 & 0.0106 \\
\hline L2 & BDL & 0.0149 & 0.0018 & 0.0827 & 0.0386 & 0.0025 & 0.0668 & 0.0057 & 0.0139 \\
\hline L3 & 0.0036 & 0.0699 & 0.0004 & 0.0798 & 0.035 & 0.0151 & 0.0637 & 0.0127 & 0.0318 \\
\hline L4 & 0.0006 & 0.0396 & BDL & 0.2668 & 0.3495 & 0.0271 & 0.0938 & 0.0186 & BDL \\
\hline L5 & 0.0003 & 0.0488 & 0.0016 & 0.0884 & 0.055 & BDL & 0.0503 & 0.0061 & 0.0101 \\
\hline L6 & BDL & 0.0143 & BDL & 0.1171 & 0.0913 & BDL & 0.0753 & BDL & 0.0081 \\
\hline L7 & 0.0018 & 0.0312 & 0.0029 & 0.0876 & 0.0405 & BDL & 0.0715 & 0.0096 & 0.0203 \\
\hline L9 & BDL & 0.1235 & BDL & 0.0104 & 0.0537 & BDL & 0.0719 & 0.0073 & 0.0128 \\
\hline L10 & BDL & 0.0367 & 0.0040 & 0.0994 & 0.0475 & 0.0169 & 0.0597 & 0.0043 & 0.0310 \\
\hline L11 & $\mathrm{BDL}$ & 0.0435 & 0.0031 & 0.0431 & 0.0324 & BDL & 0.0643 & 0.0046 & 0.0117 \\
\hline L12 & BDL & 0.0311 & BDL & 0.0653 & 0.0643 & BDL & 0.0621 & 0.0071 & BDL \\
\hline L13 & BDL & 0.0103 & 0.0003 & 0.0831 & 0.0311 & 0.0134 & 0.0563 & BDL & 0.0344 \\
\hline L14 & BDL & 0.0534 & BDL & 0.0733 & 0.0644 & BDL & 0.0732 & 0.0093 & BDL \\
\hline L15 & BDL & 0.0351 & 0.0002 & 0.0681 & 0.0536 & BDL & 0.0547 & 0.0074 & 0.0207 \\
\hline
\end{tabular}

$\mathrm{BDL}=$ Below Detection Limit.

\subsection{Industrial potential of the clay deposits}

Geotechnical and chemical evaluation of Ifon clay are employed in this study to assess the economic potential of the clay deposits in the appraisal of its suitablity as industrial raw materials. Grain size analysis of the clays indicates high percentage of fines (clay of the average of $63.02 \%$ and silt, $18.61 \%$ ) which portray the clays suitable as fillers and coating materials in paint, rubber, paper and cosmetic industries. Also, the appreciable amounts of sand-size particles $(9.5 \%-21.2 \%)$ and low firing shrinkage $(\leq 12 \%)$ make the clays suitable for large ceramic applications and brick making materials in building construction. The high clay content with the sand-size particles will 
ensure good compaction; this can also be confirmed from the compaction tests. The clays possess the permeability characteristics of good barrier soils/soil liners in waste repository. Comparison of the chemical composition of the clay deposits of the study area with the industrial specifications of known clay deposits locally and internationally (Table 7) shows vividly that the clays are suitable for the manufacture of ceramics, refractory bricks, paper, paints, rubber and fertilizer. The clay is also suitable for the manufacture of high melting clays $\left(\mathrm{SiO}_{2}: 53-73 ; \mathrm{Al}_{2} \mathrm{O}_{3}: 16-29 \% ; \mathrm{Fe}_{2} \mathrm{O}_{3}: 1-9\right.$ and $\left.\mathrm{CaO}: 0.5-2.6\right)$ (Grimshaw, 1971; Chester, 1973). The high $\mathrm{SiO}_{2}$ and $\mathrm{Al}_{2} \mathrm{O}_{3}$ of the clays of the study area compare very closely with the specifications for ceramics and refractory bricks (Table 7). The low concentrations of trace elements of the clays qualify their suitability as raw materials in chemical industries for the production of powder, metallurgical products and as a catalyst. Generally, the clays do not meet the specifications for agricultural, textile, pharmaceutical and subgrade materials. The concentrations of $\mathrm{CaO}, \mathrm{MgO}, \mathrm{Na}_{2} \mathrm{O}$ and $\mathrm{K}_{2} \mathrm{O}$ meet the specifications for the production of paper and rubber, however, the iron oxide presence in the clay is much higher than the specification. The clays of the study area compare closely with Abraka clay as shown in Table 7 except for considerable differences in $\mathrm{MgO}, \mathrm{CaO}, \mathrm{MnO}$ and $\mathrm{TiO}_{2}$. A comparison of the present study with the China clay shows that $\mathrm{SiO}_{2}$ values are higher and $\mathrm{Al}_{2} \mathrm{O}_{3}$ concentrations are lower. Both $\mathrm{SiO}_{2}$ and $\mathrm{Al}_{2} \mathrm{O}_{3}$ are higher when compared with Florida active kaolinite but compares favourably with the Plastic Fire clay of St. Louis (Huber, 1985). $\mathrm{Fe}_{2} \mathrm{O}_{3}$ concentration in the clay deposits of the study area is higher relative to the international reference clays but generally, the chemical characteristics are consistent with the results obtained from clay deposits in some other parts of Nigeria.

Table 7: Comparison of the Chemical Compositions of Ifon Clays with Some Clays in Nigeria and Industrial Specifications

\begin{tabular}{|c|c|c|c|c|c|c|c|c|c|c|c|}
\hline $\begin{array}{l}\text { Study } \\
\text { Clay }\end{array}$ & $\mathrm{SiO}_{2}(\%)$ & $\begin{array}{l}\mathrm{Al}_{2} \mathrm{O}_{3} \\
(\%)\end{array}$ & $\mathrm{Fe}_{2} \mathrm{O}_{3}(\%)$ & $\mathrm{TiO}_{2}(\%)$ & $\mathrm{MnO}(\%)$ & $\mathrm{MgO}(\%)$ & $\mathrm{CaO}(\%)$ & $\mathrm{K}_{2} \mathrm{O}(\%)$ & $\mathrm{Na}_{2} \mathrm{O}(\%)$ & $\begin{array}{l}\mathrm{P}_{2} \mathrm{O}_{5} \\
(\%)\end{array}$ & $\begin{array}{l}\mathrm{SO}_{3} \\
(\%)\end{array}$ \\
\hline $\mathrm{A}^{*}$ & 66.47 & 25.38 & 5.62 & 1.00 & 0.03 & 0.06 & 0.32 & 0.60 & 0.22 & 0.49 & 0.02 \\
\hline \multicolumn{12}{|c|}{ Reference clays (Local and International clays) } \\
\hline $\mathrm{AbC}$ & 54.22 & 16.99 & 8.12 & 0.25 & 0.38 & 2.93 & 5.90 & 0.41 & 0.37 & 0.43 & - \\
\hline AbrC & 61.92 & 20.62 & 5.00 & 3.20 & 0.11 & 0.71 & 0.02 & 0.63 & 0.14 & - & - \\
\hline FAK & 52.92 & 9.42 & 3.65 & 1.18 & - & 0.08 & 1.91 & 0.98 & 0.03 & 0.02 & - \\
\hline $\mathrm{FNaK}$ & 45.57 & 38.45 & 0.75 & 0.10 & - & 0.05 & - & 0.06 & - & - & - \\
\hline PFCS & 57.67 & 24.00 & 3.23 & - & - & 0.30 & 0.70 & 0.50 & 0.20 & 0.02 & - \\
\hline $\mathrm{ChC}$ & 46.88 & 37.65 & 0.88 & - & - & 0.13 & 0.03 & 1.60 & 0.21 & - & - \\
\hline \multicolumn{12}{|c|}{ Industrial Specifications } \\
\hline A & 47.80 & 37.00 & 0.58 & 0.03 & - & 0.16 & 0.40 & 1.10 & 0.10 & - & - \\
\hline B & 48.67 & 9.45 & 2.70 & - & - & 8.50 & 15.84 & 2.76 & 2.76 & - & - \\
\hline $\mathrm{C}$ & 67.50 & 26.50 & $0.50-1.20$ & $0.10-1.20$ & - & $0.10-0.19$ & $0.18-0.30$ & $1.10-3.10$ & $0.20-1.50$ & - & - \\
\hline $\mathrm{D}$ & 45.00 & 38.10 & 0.60 & 1.70 & - & - & - & - & - & - & - \\
\hline E & 48.70 & 36.00 & 0.82 & 0.05 & - & 0.25 & 0.06 & 2.12 & 0.10 & - & - \\
\hline $\mathrm{F}$ & 49.88 & 37.65 & 0.88 & 0.09 & - & 0.13 & 0.03 & 1.60 & 0.21 & - & - \\
\hline G & $\begin{array}{l}45.30- \\
47.90\end{array}$ & $\begin{array}{l}38.40- \\
39.9\end{array}$ & $\begin{array}{l}13.40- \\
13.80\end{array}$ & $0.10-1.00$ & - & $0.20-0.30$ & $0.03-0.25$ & $0.10-0.40$ & $0.20-0.35$ & - & - \\
\hline $\mathrm{H}$ & $51-70$ & $25-44$ & $0.5-2.4$ & $1.0-2.8$ & - & $0.2-0.7$ & $0.1-0.2$ & - & $0.8-3.5$ & - & - \\
\hline I & 46.07 & 38.00 & 0.33 & 0.50 & - & 0.01 & 0.38 & 0.43 & 0.27 & - & - \\
\hline $\mathrm{J}$ & 47.00 & 40.00 & - & - & - & - & - & - & - & - & - \\
\hline K & 44.90 & 32.35 & 0.48 & 1.80 & & & & 0.28 & 0.14 & - & - \\
\hline
\end{tabular}

$\mathrm{A}^{*}=$ Clay of the study area (Ifon Clay)

$\mathrm{AbC}=$ Abeokuta clay (Elueze and Bolarinwa, 2001)

AbrC $=$ Abraka clay (Emofurieta et al., 1994)

FAK = Florida active kaolinite (Huber, 1985)

$\mathrm{FNaK}=$ Florida non-active kaolinite (Huber, 1985)

PFCS = Plastic fire clay of St. Louis (Huber, 1985)

$\mathrm{ChC}=$ China clay (Huber, 1985)

$\mathrm{A}=$ Paper coating (Anon, 1972)

$\mathrm{B}=$ Bricks (Murray, 1960)

$\mathrm{C}=$ Ceramics (Singer and Sonja, 1971)

$\mathrm{D}=$ Textile (Keller, 1964)

$\mathrm{E}=$ Paper filler (Anon, 1972)

$\mathrm{F}=$ Agricultural (Huber, 1985)

$\mathrm{G}=$ Paints (Payne, 1961)

$\mathrm{H}=$ Refractory bricks (Parker, 1976)

I = Fertilizer (NAFCON, 1985)

$\mathrm{J}=$ Pharmaceutical (Todd, 1975)

$\mathrm{K}=$ Rubber (Keller, 1964)

\section{Conclusion}

The results of geotechnical and chemical analyses indicate the industrial utilization of the clay in Ifon. The clay can be classified as inorganic of medium to high compressibility and moderate toughness based on the unified classification of the samples. The medium to high plasticity of the clay soils guarantees their suitability as barrier material for landfill. This relatively medium to high plasticity is attributable to high clay contents. Inactive clay with moderate shrinkage values, toughness and compaction enhance its suitability for pottery and ceramics. The activity value ranged from 0.25 to 0.65 , indicating the clay mineral contents in Ifon clay as inactive. The clays possess the permeability characteristics of good barrier soils in waste repository/soil liners due to their high amount of fines and low content of gravel. The fired colour is through grayish orange to light brown and reddish brown. The reddish/brownish fired colours are preferred in the pottery and brick industries, whereas in some paper and paint industries, the creamy, whitish fired colours preferred can be acquired by bleaching the clay to produce buff colours needed for paper production. The chemical analysis reveals the dominance of silica, alumina and relatively moderate iron oxide contents in the deposits. This shows their origin from in-situ weathering of the underlying basement rocks. The high $\mathrm{SiO}_{2}$ above $66 \%$ confirmed the presence of quartz as the major constituent of Ifon clay. Based on the silica/alumina ratio, 
proportions of $\mathrm{CaO}, \mathrm{Na}_{2} \mathrm{O}$ and $\mathrm{K}_{2} \mathrm{O}$, Ifon clay can be described as Fire clay. The bulk composition compares very closely with the Plastic fire clay of St. Louis and known clays in Nigeria. Evaluation of the industrial potential of Ifon clay deposits based on their geotechnical and chemical compositions showed that they are best useful for the manufacture of ceramics, refractory bricks, paper, paints, rubber and fertilizer.

\section{References}

[1] Ademila, O. (2018).Geotechnical influence of underlying soils to pavement failure in Southwestern part of Nigeria. Malaysian Journal of Sustainable Environment, 4(2): 19-36.https://doi.org/10.24191/myse.v4i1.5604.

[2] Ademila, O. and Adebanjo, O. J. (2017). Geotechnical and mineralogical characterization of clay deposits in parts of Southwestern Nigeria. Geosciences Research, 2(2): 127-137.https://doi.org/10.22606/gr.2017.22006.

[3] Agagu, O. K. (1985). Geological guide to bituminous sediment in Southwestern Nigeria. (Unpublished monograph) Department of Geology, University of Ibadan, Ibadan.3: 17

[4] Akpokodje, E. G., Olorunfemi, B. N. and Etu-Efeotor, J. O. (1991). The composition and physical properties of some ceramic and pottery clays of Southeastern Nigeria. Journal of Mining and Geology, 27: 1-7.

[5] Anon (1972). Kaolin in the UK, English China clay deposits on its lead in world paper. Industrial Minerals, 53: 9-15.

[6] Aribisala, A. O. (1989). Sourcing of local raw material and investment opportunity in building construction. Industrial Sector Pro National Workshop.

[7] ASTM Standard D1557 (2009). Standard test methods for laboratory compaction characteristics of soil using modified effort. ASTM International West Conshohocken, PA. https://doi.org/10.1520/D1557-09.

[8] Au, W. and Chae, Y. S. (1980). Dynamic shear modulus of treated expansive soils. Journal of Geotechnical Engineering Division, 106 (GT3), 255273.

[9] Bain, D. C. and Smith, B. F. L. (1987). Chemical analysis. In: Wilson, M. J. (Ed.), A handbook of determinative methods in clay mineralogy. Blackie, Glasgow. 248-274.

[10] British Standard (BS) 1377 (1990). Methods of testing soils for civil engineering purposes. British Standards Institution, London. 2, Park Street London WI A2BS

[11] Casagrande, A. (1948). Classification and identification of soils. Transactions of the American Society of Civil Engineer, 113: 901-930.

[12] Chester, J. H. (1973). Refractories, production and properties. The iron and steel institute, 3-13, 295-314.

[13] Dogan, C. P., Kwong, K. S. and Bennet, J. P. (2002). Improved refractory materials for Slagging coal gasifiers. In Proceedings from the $27^{\text {th }}$ International Conference on coal utilization and fuel systems, Clearwater, Florida.

[14] Elueze, A. A. And Bolarinwa, A. T. (2001). Appraisal of the residual and sedimentary clays in parts of Abeokuta area, southwestern Nigeria. Journal of Mining and Geology, 37: 7-14.

[15] Emofurieta, W. O., Ogundimu, T. O. and Imeokparia, F. C. (1994). Mineralogical, Geochemical and Economic appraisal of some clay and shale deposits in Southwestern and Northeastern Nigeria. Journal of Mining and Geology, 30: 151-159.

[16] Federal Ministry of Works and Housing (FMWH) (2000). General specification for roads and bridges, 2: 137-275.

[17] Gidigasu, M. D. (1976). Laterite soil engineering pedo-genesis and engineering principles, Amsterdam Elsevier Scientific, New York. 554.

[18] Grim, R. E. (1968). Applied clay mineralogy. $2^{\text {nd }}$ edition McGraw Hill, New York. 596.

[19] Gupta, O. P. (2008). Elements of fuels furnace and refractories, $5^{\text {th }}$ edition, second reprint, Kharnna publishers; New Delhi.

[20] Grimshaw, R. W. (1971). The Chemistry and Physics of clays and allied ceramic materials," $3^{\text {rd }}$ Edition, Ernest Benn Limited, 801-802

[21] Huber, J. M. (1985). Kaolin Clays and their industrial uses. Huber Corporation (Clay Division), Georgia, USA. 64.

[22] Keller, W. D. (1964). Clays. In: Kirk-Othmer Encyclopedia of Chemical Technology, $2^{\text {nd }}$ edition. John Wiley and Sons Incorporation, New York, USA. 5: 541-585

[23] Lambe, T. W. 1954. The permeability of fine-grained soils: Symposium on permeability of soils. ASTM, Special Technical Publication, 163.

[24] Madedor, A. C. (1992). The impact of building materials research on low cost housing development in Nigeria. Engineering Focus. Publication of the Nigerian Society of Engineers, 4(2): 37-41.

[25] Mesida, E. A. (1978). Utilization of some lateritic clay for burnt bricks. Journal of Mining and Geology, 28(2): 211-220.

[26] Mpuchane, S., Ekosse, G. E., Gashe, B., Morobe, I. and Coetzee, S. (2008). Mineralogy of Southern African medicinal and cosmetic clays and their effects on the growth of selected test micro-organisms. Fresen. Environmental Bulletin, 15: 547-557.

[27] Murray, H. H. (1960). Clay industrial minerals and rocks. New York: American Institute of Mining, Metallurgy and Petroleum Engineers. $259-284$.

[28] National Fertilizer Company of Nigeria (NAFCON) (1985). Tender document for the supply of kaolin from Nigeria sources, 65.

[29] Nesbitt, H. W., Markovics, G. and Price, R. C. 1980. Chemical processes affecting alkalis and alkalis earths during continental weathering; GeochimCosmochim Acta. 44: 1659-1666.https://doi.org/10.1016/0016-7037(80)90218-5.

[30] Newman, A. C. D. (1987). Chemistry of clays and clay minerals. Mineralogical Society Monograph, 6, Longman Scientific and Technical, Harlow, Essex, England. 480.

[31] Parker, E. R. (1976). Minerals data book for Engineers and scientists. McGraw Hill Book Co., New York. 283.

[32] Payne, H. F. (1961). Organic coating technology: pigments and pigmented coatings: John Wiley and Sons, Inc. New York. 796.https://doi.org/10.1149/1.2428201.

[33] Robert, F. (1994). Basic notes on clays and clay bodies. Retrieved from http://cavemanchemistry.com/oldcave/projects/pottery/basic_clays.html.

[34] Rowe, R. K., Quigley, R. M. and Booker, J. R. (1995). Clayey barrier systems for waste disposal facilities," E and FN Spon, London.https://doi.org/10.4324/9780203302064

[35] Singer, F. and Sonja, S. S. (1971). Industrial ceramics publication. Chapman and Hall, London, UK. 18-56.

[36] Skempton, A. W. (1953). Activity of clays. In: Proceedings of the $3^{\text {rd }}$ International Conference on soil mechanics and foundation engineering. 1: 195-200.

[37] Todd, R. G. 1975. British Pharmaceutical Codex Publication, R. G. Todd (ed.), 234-236. The Pharmaceutical Press, London, UK.

[38] Velde, B. (1995). Composition and mineralogy of clay minerals, in Velde, B. (ed.), Origin and mineralogy of clays. New York, Springer-Verlag. 842.https://doi.org/10.1007/978-3-662-12648-6_2_.

[39] Whitlow, R. (1995). Basic soil mechanics," $3^{\text {rd }}$ Edition Addison Wesley Longman Limited, Edinburgh gate.

[40] Wronkiewicz, D. J. and Condie, K. C. (1987). Geochemistry of Archean shales from the Witwatersrand Super group, South Africa: source area weathering and provenance: GeochimCosmochim Acta, 51: 2401-2416.https://doi.org/10.1016/0016-7037(87)90293-6. 